\title{
Growth of Potato Plants of the 'Asterix' Cultivar and Accumulation of Nutrients
}

\author{
Juan W. Mendoza-Cortez ${ }^{1}$, Arthur B. Cecílio-Filho ${ }^{1}$, Murilo O. Rosa ${ }^{1} \&$ Camila S. Nascimento ${ }^{1}$ \\ ${ }^{1}$ São Paulo State University, Jaboticabal, São Paulo, Brazil \\ Correspondence: Arthur B. Cecílio-Filho, São Paulo State University, Via de acesso Prof. Paulo Donato Castellane, \\ s/n, 14884-900, Jaboticabal, São Paulo, Brazil. Tel: 55-16-3209-2668. E-mail: rutra@fcav.unesp.br
}

Received: May 5, 2013 Accepted: June 5, 2013 Online Published: June 16, 2013

doi:10.5539/jas.v5n7p217 URL: http://dx.doi.org/10.5539/jas.v5n7p217

\begin{abstract}
The objective of this research work was to quantify both the development of potato plants of the 'Asterix' cultivar and the accumulation of nutrients by the plants. The experiment was carried out at Perdizes, state of Minas Gerais, Brazil, in a randomized complete block design with seven treatments (sampling moments) and three replications. The spatial arrangement of the plants in the field was of $0.80 \mathrm{~m}$ between rows and $0.35 \mathrm{~m}$ between plants in the row. Plant samples were taken 30, 42, 54, 66, 78, 90, and 114 days after planting (DAP) for the determinations of plant dry matter and accumulated nutrients. The potato plant was slow to grow up to 42 DAP and the highest rate of dry matter accumulation was observed between 51 and 90 DAP. Plant cycle was of 97 days and total productivity of 44 $\mathrm{t} \mathrm{ha}^{-1}$. Total macro nutrients accumulated by the plants up to 90 DAP were of $369.3,184.0,42.7,18.0,16.2$, and $13.8 \mathrm{~kg} \mathrm{ha}^{-1}$ of K, N, Ca, P, Mg, and S, respectively. The micronutrients Fe, Mn, Zn, B, and Cu were found to have reached values of $1,225,525,439,164$, and $96 \mathrm{~g} \mathrm{ha}^{-1}$, respectively.
\end{abstract}

Keywords: nutrient absorption, plant nutrition, Solanum tuberosum L.

\section{Introduction}

Potato (Solanum tuberosum) tubers are the fourth more important source of food for mankind only surpassed by rice, wheat, and corn (Filgueira, 2003). World production of potatoes is of 329556911 tons harvested from an area of 18326242 hectares, this meaning a mean productivity of $18 \mathrm{tha}^{-1}$. The biggest potato producers in the world are China, Russia, Ukraine, and the United States (Food and Agriculture Organization of the United Nations [FAO], 2011).

Potatoes are one of the most important vegetables in Brazil with a total production of 3443737 tons cultivated in an area of 140987 hectares, this meaning a mean productivity of $24 \mathrm{t} \mathrm{ha}^{-1}$. If compared to yields verified in developed countries such as the United States, the Netherlands, Germany, and France (between 44 and $46 \mathrm{tha}^{-1}$ ), the Brazilian productivity is considered low (FAO, 2011; Instituto Brasileiro de Geografia e Estatística [IBGE], 2011).

Factors such as plant mineral nutrition and soil fertilization help to explain such low productivity. Plant nutrition affects tubers productivity and quality, which is in turn influenced by soil fertilization whose efficiency is dependent on fertilizers doses and time of application.

Research works concerned with the quantification of plant growth and the march of absorption or accumulation of nutrients are basic to improve the efficiency of soil fertilization, optimize production, and reduce environmental impacts by the excess of fertilizers. Several research works (Alvarez-Sánchez et al., 1999; Aguilar et al., 2001; Alva et al., 2002; Yorinori, 2003; Heard, 2004; Cabalceta et al., 2005; Favoretto, 2005; Mora-Aguilar et al., 2005; Sharifi et al., 2005; Geremew et al., 2007; Horneck \& Rosen, 2008; Coraspe-León et al., 2009; Ñ́stez et al., 2009; Fernandes, 2010) viewing to evaluate potato plant growth and accumulation of nutrients have shown that the amounts of extracted nutrients vary according to cultivation conditions.

Potato plant metabolism and cycle were different under different climatic conditions. Mainly temperature, photoperiod, and precipitation have been reported to significantly influence potato plant growth and the accumulation of dry matter this leading to differences in nutrients absorption and accumulation (Sancho, 1999; Bertsch, 2003). Thus the evaluation of potato plant cultivars demand for nutrients is necessary to be carried out under the local conditions where they are cultivated. 
With these considerations in mind, the present research work viewed to quantify the growth and the accumulation of macro and micronutrients by potato plants of the 'Asterix' cultivar and simultaneously obtain the equations which best represent them.

\section{Materials and Methods}

The experiment was set and carried out in a private rural property located at the municipality of Perdizes $\left(19^{\circ} 21^{\prime} 10^{\prime \prime} \mathrm{S}\right.$ and $\left.47^{\circ} 17^{\prime} 34^{\prime \prime} \mathrm{W}\right)$, state of Minas Gerais, Brazil, from July 5 to October 27 of 2009 in a soil classified by Empresa Brasileira de Pesquisa Agropecuária [EMBRAPA] (2006) as a Red Yellow Argisol. The dominant climatic condition in the region is that of tropical altitude with yearly mean temperature and pluvial precipitation of $20.4^{\circ} \mathrm{C}$ and $1,574.7 \mathrm{~mm}$.

A chemical analysis carried out in soil samples of the region taken at depths between 0 and $20 \mathrm{~cm}$ showed the following results: $\mathrm{pH}_{(\mathrm{CaCl} 2)}=5.4$; organic matter $=35 \mathrm{~g} \cdot \mathrm{dm}^{-3} ; \mathrm{P}_{(\text {Mehlich-1) }}$ and $\mathrm{K}=2.7$ and $96 \mathrm{mg} \cdot \mathrm{dm}^{-3}$, respectively; $\mathrm{Ca}, \mathrm{Mg}, \mathrm{H}+\mathrm{Al}$, and $\mathrm{Al}=35,17,31$, and $0 \mathrm{mmol}_{\mathrm{c}} \cdot \mathrm{dm}^{-3}$, respectively, and soil bases saturation of $64 \%$. The physical analysis of the soil showed the contents of sand, silt, and clay to be, respectively, of 391, 232, and $377 \mathrm{~g} \mathrm{~kg}^{-1}$.

Seed tubers of the cultivar 'Asterix' were planted in rows so that the distance between plants would be of $0.35 \mathrm{~m}$ and between rows of $0.80 \mathrm{~m}$. Soil liming was not made for, according to Fontes (1999), it is not necessary when soil bases saturation is higher than $60 \%$. At planting, 40, 420, and $30 \mathrm{~kg} \mathrm{ha}^{-1}$ of $\mathrm{N}_{2} \mathrm{P}_{2} \mathrm{O}_{5}$, and $\mathrm{K}_{2} \mathrm{O}$, respectively, were placed at the bottom of the row. At 27 days after planting (DAP) 150 and $120 \mathrm{~kg} \mathrm{ha}^{-1}$ of, respectively, $\mathrm{N}$ and $\mathrm{K}_{2} \mathrm{O}$ were applied to complement soil fertilization.

In the field, the experiment was set according to a randomized complete block design with three repetitions and seven treatments (sampling times). Potato plants started to be collected 30 DAP and then at each 12 days, with the exception of the last one which was collected 24 days after the penultimate. Plants for sampling purpose took place at 30, 42, 54, 66, 78, 90, and 114 DAP. At each collecting moment, three plants per repetition were taken. At 114 DAP the samples were formed just by tubers since the plant aerial part had already died.

Brought to a laboratory, the plants were divided in leaves, stems, and tubers. The vegetative materials were washed in running water and then in deionized water. That was followed by the drying of the materials in an oven of forced ventilation at a temperature of $65^{\circ} \mathrm{C}$ till constant weight. After that, the materials had their weight determined in a digital scale with a precision of $0.01 \mathrm{~g}$. These materials were ground and their contents of macro and micronutrients determined according to procedures described in Bataglia, Furlani, Teixeira, Furlani, and Gallo (1983). Based on the results, the accumulated amounts of each nutrient in the stem, leaves, and tubers were calculated. Polynomial and logistic $\left[\mathrm{Y}=\mathrm{A} / 1+\mathrm{e}^{-\mathrm{K}(\mathrm{X}-\mathrm{Xc})}\right.$, where $\mathrm{Y}=$ mean value of the evaluated characteristic; $\mathrm{A}=$ asymptotic maximum (maximum quantity); $\mathrm{K}=$ mean increment rate of the accumulated quantity; $\mathrm{X}=$ time (days); $\mathrm{Xc}=$ time necessary for half the maximum quantity to be reached] functions were used to represent growth and nutrients accumulation data with the help of the software ORIGIN 6.0.

\section{Results and Discussion}

\subsection{Potato Growth}

Potato plant growth expressed in terms of dry matter accumulation was slow up to 42 DAP (Figure 1a). Tuber formation was started $37 \mathrm{DAP}$, that is after $32 \%$ of the plant cycle had elapsed and when the dry masses of leaves and stems were, respectively, of 9.0 and $7.0 \mathrm{~g} \mathrm{plant}^{-1}$, corresponding to 25 and $63 \%$ of their maximum.

The dry matter partition favored stems and leaves up to 44 and 50 DAP, respectively. After those periods, dry matter started to be allocated essentially for tubers (Figure 1a). 


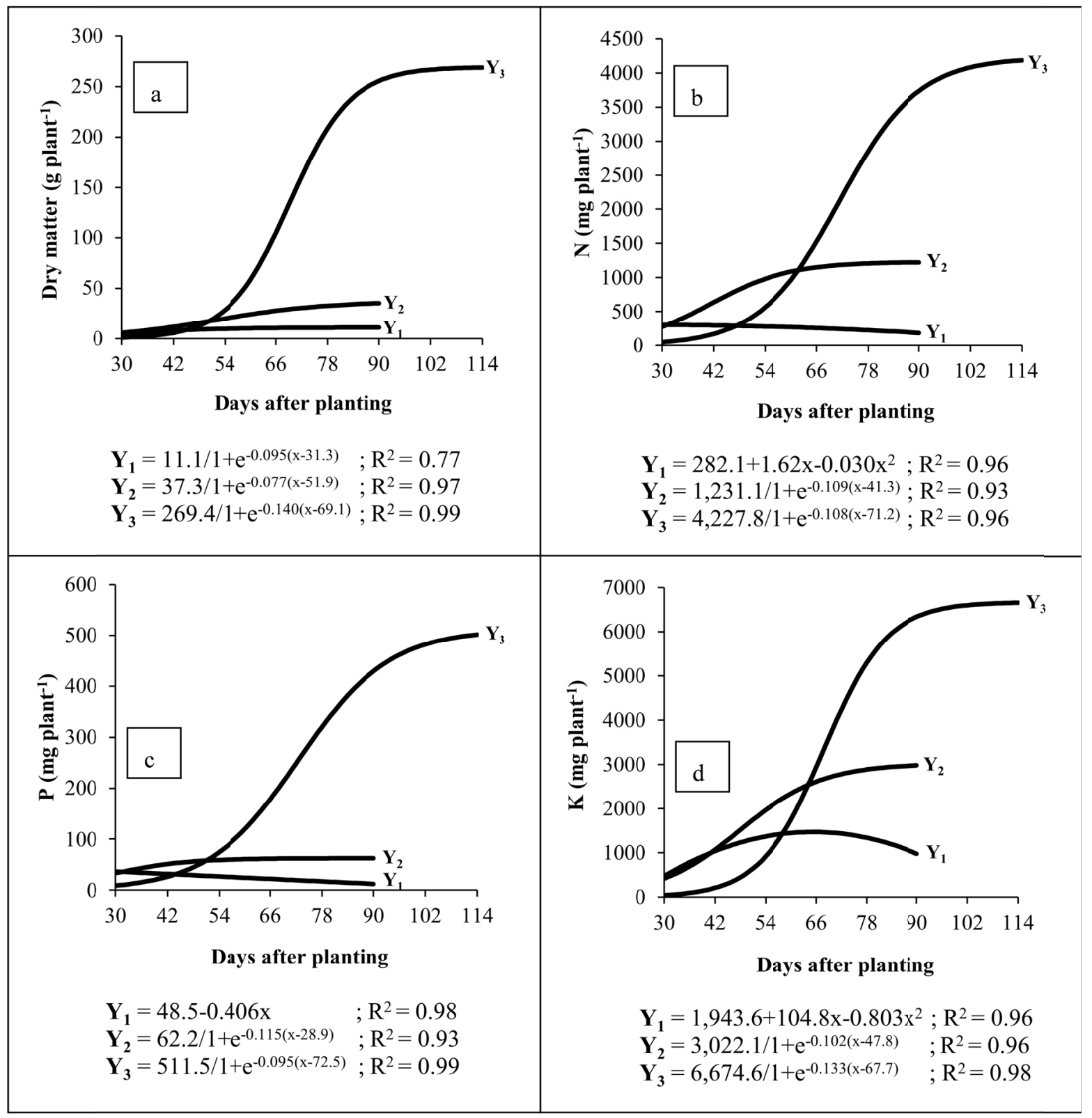

Figure 1. Dry matter (a), N (b), P (c) and $\mathrm{K}(\mathrm{d})$ accumulation in stems $\left(\mathrm{Y}_{1}\right)$, leaves $\left(\mathrm{Y}_{2}\right)$, and tubers $\left(\mathrm{Y}_{3}\right)$ of potato (cv. 'Asterix') plants during their growth cycle

Most of the dry matter was accumulated between 51 and 90 DAP (Figure 1a) with a mean increment rate of $6.5 \mathrm{~g}$ plant $^{-1} \mathrm{day}^{-1}$. In that interval of time, the tubers accumulated $239 \mathrm{~g} \mathrm{plant}^{-1}$, corresponding to $89 \%$ of the total attained at 114 DAP, that is, at the last sample collected, 17 days after the senescence of the plant aerial part. Dry matter accumulated in tubers at a rate of $6.1 \mathrm{~g} \mathrm{plant}^{-1}$ day $^{-1}$ or $218 \mathrm{~kg} \mathrm{ha}^{-1} \mathrm{day}^{-1}$ according to the plant population adopted in this experiment, that is 35714 plants $\mathrm{ha}^{-1}$. This is crucial information for the decision as to the desiccation of the plants viewing the anticipation of harvest since it permits the farmer to analyze whether the loss in yield attributable to the number of days of harvest anticipation is economically compensated by the potato value.

At 90 DAP - the last collect of samples with plants still bearing leaves - the amounts of dry matter accumulated by leaves, stems, and tubers were of 35.4, 11.1, and $255.6 \mathrm{~g} \mathrm{plant}^{-1}$, respectively (Figure 1a). At that moment of the plant cycle, the amount of dry matter accumulated in the plant aerial part (stems and leaves) was rather small if compared to that accumulated in tubers at 114 DAP (269 $\left.\mathrm{g} \mathrm{plant}^{-1}\right)$ corresponding to 11.2 (leaves), 3.5 (stems), and $85 \%$ (tubers) of the total accumulated ( $\left.315.5 \mathrm{~g} \mathrm{plant}^{-1}\right)$. Several research works show that the total amount of 
dry matter allocated to the tubers vary between 69 and $90 \%$ of the plant total (Alvarez-Sánchez et al., 1999; Aguilar et al., 2001; Alva et al., 2002; Yorinori, 2003; Mora-Aguilar et al., 2005; Sharifi et al., 2005; Geremew et al., 2007; Horneck \& Rosen, 2008; Nústez et al., 2009; Fernandes, 2010). This variation may be explained by genotype effect, cultivation time, environmental factors specially temperature and photoperiod, soil fertilization and the level of senescence of the plant aerial part at the moment the sample was taken.

Between the penultimate and the last harvest, tubers dry matter had an increment of 5\% (13.4 g plant $\left.{ }^{-1}\right)$, the equivalent to $478 \mathrm{~kg} \mathrm{ha}^{-1}$. Plant cycle was 97 days, when a productivity reached at $44 \mathrm{t} \mathrm{ha}^{-1}$, a value close to that $\left(40 \mathrm{t} \mathrm{ha}^{-1}\right)$ reported by Fernandes (2010) in a research work with potato plants of the same cultivar.

\subsection{Macronutrients}

Starting with the first evaluation, it was possible to verify decrements in the accumulation of $\mathrm{N}$ in the stems up to the end of the plant cycle in comparison with leaves and tubers. At 30 DAP there were $303.7 \mathrm{mg} \mathrm{plant}^{-1}$ of N whereas at 90 DAP that amount had dropped to $184.2 \mathrm{~g} \mathrm{plant}^{-1}$ (Figure 1b).

Up to 61 DAP, N accumulation occurred more in leaves than in the tubers, reaching $1101 \mathrm{mg} \mathrm{plant}^{-1}$. Starting at that point, $\mathrm{N}$ accumulation in the leaves began to decelerate probably due to the drain power of the tubers. $\mathrm{N}$ accumulation in the leaves is important since this element takes part of the growth and cell differentiation processes (Malavolta, 2006). Consequently leaves grow more vigorously, radiation, water, and nutrients are absorbed more efficiently this leading to the production of larger amounts of dry matter to be accumulated by the tubers.

Accumulation of $\mathrm{N}$ in the tubers was verified to undergo a sharp increase from 42 to 90 DAP. In that interval of 48 days, tubers accumulated $3565.4 \mathrm{mg}$ plant $^{-1}$, this representing $85.2 \%$ of the total accumulated by that plant part (Figure 1b). Between 42 and 90 DAP, Fernandes (2010) also verified higher $\mathrm{N}$ accumulated in tubers of the 'Asterix' cultivar (2251.5 $\left.\mathrm{mg} \mathrm{plant}^{-1}\right)$, representing $84.3 \%$ of the total accumulated in this organ.

At 90 DAP, the amounts of $\mathrm{N}$ accumulated in tubers (3736.5 mg plant $\left.{ }^{-1}\right)$, stems $\left(184.2 \mathrm{mg} \mathrm{plant}^{-1}\right)$, and in leaves (1255 mg plant ${ }^{-1}$ ) corresponded to 67,3 , and $22 \%$ of the total accumulation (5596 mg plant ${ }^{-1}$ ). At 114 DAP when there were only tubers, the total $\mathrm{N}$ accumulated was of $4187 \mathrm{mg} \mathrm{plant}^{-1}$. Alva et al. (2002), working with the cultivar 'Hilite Russet', found a total (leaves, stem, and tubers) of accumulated $\mathrm{N}$ of $5504.4 \mathrm{mg} \mathrm{plant}^{-1}$, a value quite close to the amount found in this work. Fernandes (2010) verified values of accumulated N between 2464 and $3276 \mathrm{mg} \mathrm{plant}^{-1}$ in the cultivars 'Ágata', 'Asterix', 'Atlantic', 'Markies', and 'Mondial'. In a similar work, Yorinori (2003) found a total of accumulated $\mathrm{N}$ in plants of the 'Atlantis' cultivar was $3362 \mathrm{mg} \mathrm{plant}^{-1}$ in the rainy season and $2861 \mathrm{mg}$ plant $^{-1}$ in the dry season. Heard (2004) reported total accumulated $\mathrm{N}$ was $7562 \mathrm{mg}$ plant $^{-1}$ in the cultivar 'Ranger Russet'.

Up to 50 and 43 DAP, P accumulated mainly in leaves and stems, respectively. From 51 DAP onwards, P accumulated essentially in tubers. At 90 DAP, the total amount of $P$ accumulated in tubers was of $430 \mathrm{mg}^{-1 a n t^{-1}}$, a value larger than that of the leaves $\left(62.2 \mathrm{mg} \mathrm{plant}^{-1}\right)$ and of the stems $\left(12.0 \mathrm{mg} \mathrm{plant}^{-1}\right)$, as shown in Figure 1c. These results corroborate those reported by Alvarez-Sánchez et al. (1999). In stems, the accumulation of $P$ started to decrease from 30 DAP onwards $\left(36.4 \mathrm{mg} \mathrm{plant}^{-1}\right)$ up to $90 \mathrm{DAP}\left(12.0 \mathrm{mg} \mathrm{plant}^{-1}\right)$ whereas in the leaves a slight increase was observed between 30 and 54 DAP $\left(26 \mathrm{mg} \mathrm{plant}^{-1}\right)$. After that moment, up to 90 DAP, P content in leaves became constant (Figure 1c).

Between 42 and 90 DAP, P content in tubers grew vigorously (Figure 1c) reaching a total of $403 \mathrm{mg} \mathrm{plant}^{-1}$, which corresponded to $70 \%$ of the total accumulated in the plant $\left(576 \mathrm{mg}\right.$ plant $\left.^{-1}\right)$. Yorinori (2003) showed that the total $\mathrm{P}$ accumulated in the plants (leaves, stems, and tubers) of the 'Atlantis' cultivar were $422.9 \mathrm{mg} \mathrm{plant}^{-1}$ during the rainy season and $366.3 \mathrm{mg}$ plant $^{-1}$ during the dry season these values being lower than the one found in this work (504.2 $\left.\mathrm{mg} \mathrm{plant}^{-1}\right)$ at 90 DAP when leaves and stems had not dried up. Data published by Fernandes (2010) show that, at 97 DAP, plants of the 'Agata', 'Atlantic', and 'Markies' cultivars had accumulated a total of $392 \mathrm{mg}$ plant $^{-1}$ and those of the cultivars 'Asterix' and 'Mondial' of $504 \mathrm{mg}$ plant $^{-1}$, a value close to the one we found in this investigation (504.2 $\mathrm{mg}^{-1}$ plant $^{-1}$ ) at 90 DAP. The P value reported by Heard (2004), such as was the case of $\mathrm{N}$, is larger $\left(1277 \mathrm{mg} \mathrm{plant}^{-1}\right)$ than the one found in this work.

Of all nutrients, $\mathrm{K}$ was the most absorbed by the potato plant corroborating data published by Cabalceta et al. (2005), Horneck and Rosen (2008), and Fernandes (2010). Yorinori (2003) verified K to be more absorbed than $\mathrm{N}$ during the rainy season and the opposite during the dry season. Potassium plays a very important role in the elaboration of carbohydrates and their mobilization to the tubers (Bertsch, 2003).

Potassium accumulation in tubers was observed to occur from 42 to 90 DAP. The highest amount of $\mathrm{K}$ in the tubers was observed 114 DAP: $6600 \mathrm{mg}$ plant $^{-1}$. In the leaves and stems the maxima, respectively, of 2981.74 
and $978.91 \mathrm{mg} \mathrm{plant}^{-1}$ were reached 90 DAP (Figure 1d). Larger amounts of $\mathrm{K}$ in the tubers than in other plant parts were also reported by Yorinori (2003) in plants of cultivar 'Atlantic' and Fernandes (2010) in cultivars 'Agata', 'Asterix', 'Atlantic', 'Markies', and 'Mondial' in which the total amount of accumulated K was between 3210 and $7168 \mathrm{mg}$ plant $^{-1}$. These values are less than the one found in this research 90 DAP (penultimate sample), that is, $10302 \mathrm{mg} \mathrm{plant}^{-1}$. The highest amount (more than $11640 \mathrm{mg} \mathrm{plant}^{-1}$ ) of K was reported by Heard (2004).

The potato leaves showed a strong increment in Ca accumulation from 42 to 78 DAP, reaching, in that period, a total of $647.3 \mathrm{mg} \mathrm{plant}^{-1}$ which represents $72 \%$ of the total $\mathrm{Ca}$ accumulated by leaves up to 90 DAP. In the stems, the highest amounts of accumulated Ca were observed between 30 and 59 DAP. The amount accumulated during that period of 29 days was of $153 \mathrm{mg}$ plant $^{-1}$, which corresponded to $70 \%$ of the total accumulated by stems up to 90 DAP. The accumulation of $\mathrm{Ca}$ in tubers was kept practically constant with a slightly higher accumulation starting at 66 DAP. Between 90 and 114 DAP, the amount of Ca in tubers went from 73.7 to $100.5 \mathrm{mg}^{\text {plant }}{ }^{-1}$ (Figure 2e).

The results showed that $\mathrm{Ca}$, differently from the other nutrients, accumulated more in the stem and leaves. At 90 DAP, the leaves had $902 \mathrm{mg}$ plant $^{-1}$, the stem, $217.2 \mathrm{mg} \mathrm{plant}^{-1}$, and the tubers just $73.7 \mathrm{mg}$ plant $^{-1}$. The amount in the tubers was of $6 \%$ of the total accumulated by the plant (1219 $\left.\mathrm{mg} \mathrm{plant}^{-1}\right)$ whereas leaves and stem had, at 90 DAP, 74 and $18 \%$ of the total Ca accumulated by the plant.

Fernandes (2010), with the cultivar 'Asterix', and Heard (2004), with cultivar 'Ranger Russet' found totals of 1400 and $2258 \mathrm{mg} \mathrm{plant}^{-1}$ of Ca. Yorinori (2003) reported values of $521.5 \mathrm{mg} \mathrm{plant}^{-1}$ during the rainy season and $350.2 \mathrm{mg}$ plant $^{-1}$ during the dry season.

The intense transpiration taking place in the leaves in comparison with the other parts of the plant causes Ca to be transported predominantly to the leaves. Since $\mathrm{Ca}$ is practically immovable in the plant, most of it will be found in the leaves in the mature plant and only a small proportion in the tubers, this being the opposite of what was verified with $\mathrm{N}, \mathrm{P}$, and $\mathrm{K}$. The small proportions with which Ca occurs in tubers were confirmed by results reported by Yorinori (2003), Heard (2004), Coraspe-León et al. (2009), and Fernandes (2010).

Stem and leaves showed different amounts of $\mathrm{Mg}$ but the period of the largest demand was the same for both plant parts when they reached their maximum concentration between 30 and 66 DAP, with $29.2 \mathrm{mg}$ plant $^{-1}$ in the stem and $81.9 \mathrm{mg}^{-1}$ plant $^{-1}$ in the leaves, these values representing, respectively, 60 and $74 \%$ of the total accumulated by these plant parts at 90 DAP. In the tubers, most of the Mg accumulated between 48 and 96 DAP with a value of $291 \mathrm{mg}$ plant $^{-1}$, this amount representing $90 \%$ of the total accumulated by the tubers at 114 DAP (Figure 2f). 


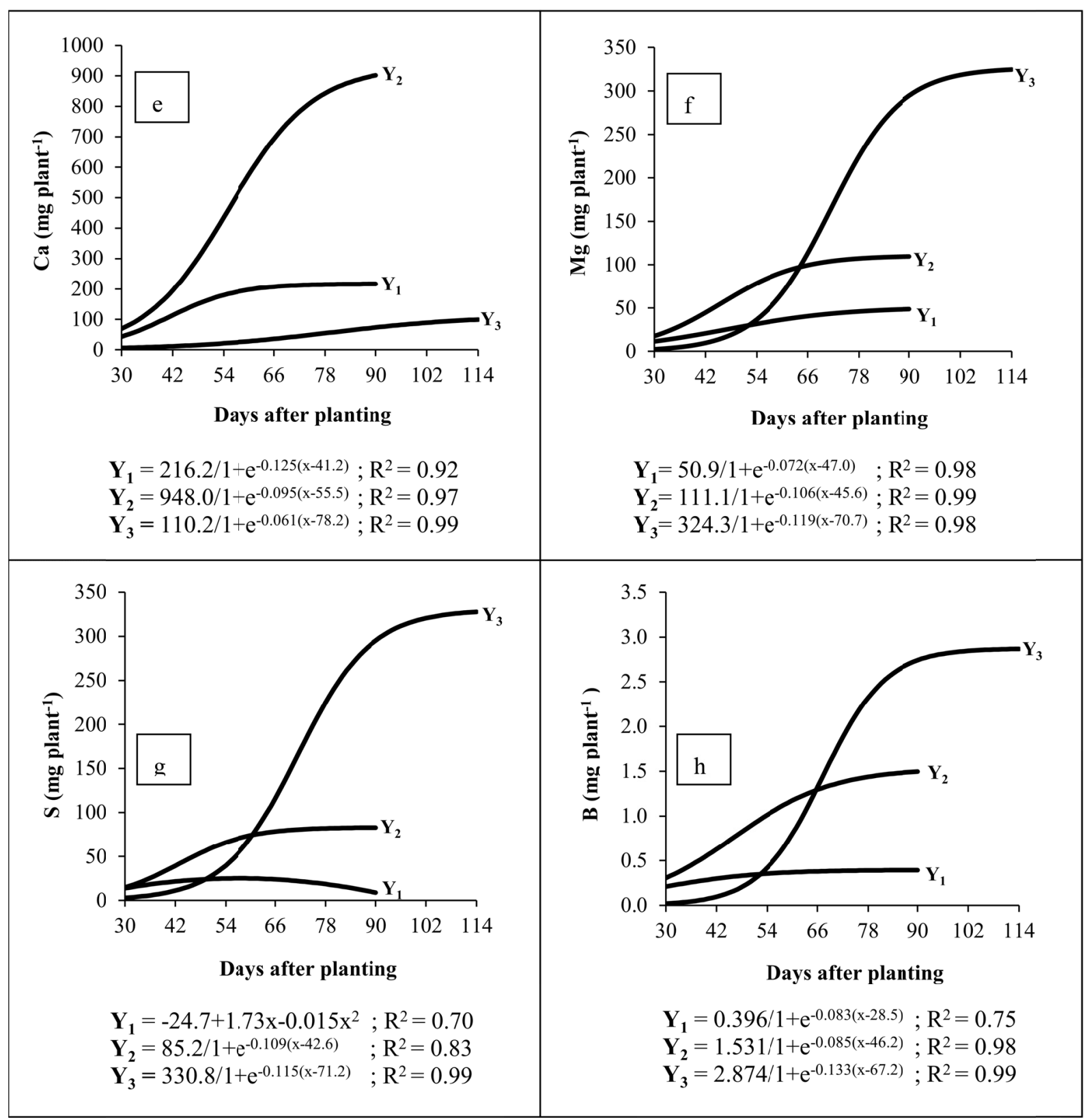

Figure 2. Ca (e), $\mathrm{Mg}(\mathrm{f}), \mathrm{S}(\mathrm{g})$ and $\mathrm{B}(\mathrm{h})$ accumulation in stems $\left(\mathrm{Y}_{1}\right)$, leaves $\left(\mathrm{Y}_{2}\right)$, and tubers $\left(\mathrm{Y}_{3}\right)$ of potato (cv. 'Asterix') plants during their growth cycle

At 90 DAP the largest amount of Mg was found in tubers (294.7 $\mathrm{mg} \mathrm{plant}^{-1}$ ) followed by the leaves $(109.7 \mathrm{mg}$ plant $\left.^{-1}\right)$ and by the stem (48.7 mg plant $\left.{ }^{-1}\right)$, these being data similar to those reported by Yorinori (2003) and Cabalceta et al. (2005) who also verified the tubers to be the plant part where Mg accumulated most. Heard (2004), Coraspe-León et al. (2009), and Fernandes (2010) have, nonetheless, verified Mg to accumulate mainly in the leaves.

Total Mg accumulated in the plant was of $483.1 \mathrm{mg} \mathrm{plant}^{-1}$, a value larger than the one reported by Fernandes (2010) in potato plants of the same cultivar (336 mg plant ${ }^{-1}$ ) and by Yorinori (2003), that is, $344 \mathrm{mg} \mathrm{plant}^{-1}$ during the rainy season, although Heard (2004) found a much larger value: $1917 \mathrm{mg} \mathrm{plant}^{-1}$.

Leaves were, up to $57 \mathrm{DAP}$, the plant part where most of the $\mathrm{S}$ accumulated: a total of $55.8 \mathrm{mg}$ plant $^{-1}$, this value representing $67 \%$ of the total accumulated in them at 90 DAP. In the stems, the amount of S at 30 DAP was of $14.5 \mathrm{mg}$ plant $^{-1}$, a value which was continually reduced up to $90 \mathrm{DAP}$, when it was of $8.7 \mathrm{mg} \mathrm{plant}^{-1}$ (Figure $2 \mathrm{~g}$ ). In plants of the 'Asterix' cultivar, Fernandes (2010) also verified the S content of stems to decrease till the plant 
cycle end. Tubers showed the highest accumulation of S between 44 and 93 DAP with $290.9 \mathrm{mg}$ plant $^{-1}$, this representing $89 \%$ of the total accumulated in that tissue up to 114 DAP.

At 90 DAP, the largest amount of $\mathrm{S}$ was verified in tubers $\left(295.3 \mathrm{mg} \mathrm{plant}^{-1}\right)$, followed by the leaves $(82.8 \mathrm{mg}$ plant $^{-1}$ ) and stems (8.7 mg plant $\left.{ }^{-1}\right)$, as shown in Figure 2c. Similar data were reported by Yorinori (2003), Heard (2004), and Cabalceta et al. (2005). Data published by Coraspe-León et al. (2009) though pointed the leaves and stems the plant parts where most of the $\mathrm{S}$ accumulated.

Total accumulated S was of $419.2 \mathrm{mg} \mathrm{plant}^{-1}$, a value larger than the one found by Yorinori (2003), that is, 260.6 $\mathrm{mg}$ plant ${ }^{-1}$ in plants of the 'Atlantic' cultivar grown during the rainy season and $161.4 \mathrm{mg} \mathrm{plant}^{-1}$ in those grown during the dry season. Heard (2004), on the other hand, reported to have found $988 \mathrm{mg} \mathrm{plant}^{-1}$ of S.

\subsection{Micronutrients}

The largest amounts of B accumulated in leaves $\left(1.3 \mathrm{mg} \mathrm{plant}^{-1}\right)$ and stems $\left(0.3 \mathrm{mg}\right.$ plant $\left.^{-1}\right)$ took place up to 64 and 52 DAP, corresponding to 87 and $76 \%$ of the total accumulated in those plant parts, respectively. In tubers the great increment in B content took place between 54 and $90 \mathrm{DAP}$ with $2.3 \mathrm{mg} \mathrm{plant}^{-1}$, which corresponded to $56 \%$ of the total B accumulated in that plant part at 114 DAP (Figure $2 \mathrm{~h}$ ).

The maximum amount of B in tubers was found at $114 \mathrm{DAP}$ and was of $2.9 \mathrm{mg}^{\mathrm{p}} \mathrm{plant}^{-1}$. Yorinori (2003), in tubers of the cultivar 'Atlantic', found 1.8 and $1.6 \mathrm{mg} \mathrm{plant}^{-1}$ in plants grown, respectively, during the rainy and the dry seasons. Working with potato plants of the cultivar 'Asterix', Fernandes (2010) found the highest amount $\left(1.0 \mathrm{mg} \mathrm{plant}^{-1}\right)$ of $\mathrm{B}$ in the tubers at the end of the plant cycle.

Copper accumulation in stems practically did not increase from the plant cycle beginning to 90 DAP, a moment when it was of $0.13 \mathrm{mg}$ plant $^{-1}$. In that period, leaves accumulated $1.2 \mathrm{mg}^{-1 a n t^{-1}}$ and tubers $1.3 \mathrm{mg} \mathrm{plant}^{-1}$ (Figure 3i) thus totalizing $2.6 \mathrm{mg} \mathrm{plant}^{-1}$. In leaves, the highest accumulation of $\mathrm{Cu}$ took place between 42 and 78 DAP when a total of $1.1 \mathrm{mg} \mathrm{plant}^{-1}$ was reached. At $114 \mathrm{DAP}$, the total amount of $\mathrm{Cu}$ in tubers was of only 1.5 mg plant ${ }^{-1}$. Yorinori (2003) also found the tubers to be the plant part with most of the accumulated $\mathrm{Cu}(0.7$ and $0.9 \mathrm{mg} \cdot$ plant $\left.^{-1}\right)$ followed by the leaves $\left(0.3\right.$ and $\left.0.3 \mathrm{mg} \mathrm{plant}^{-1}\right)$, and stems $\left(0.1\right.$ and $\left.0.1 \mathrm{mg} \mathrm{plant}^{-1}\right)$ in plants growing, respectively, in the rainy and the dry seasons. Similar results were reported by Fernandes (2010) in plants of the cultivar 'Asterix': $3.9,0.4$, and $0.1 \mathrm{mg} \mathrm{plant}^{-1}$ in, respectively, tubers, leaves, and stems.

The largest amount of $\mathrm{Cu}$ in tubers took place from 45 to 90 DAP with a total accumulated in that period of 1.2 mg plant ${ }^{-1}$, this representing $80 \%$ of $1.5 \mathrm{mg} \mathrm{plant}^{-1}$ which was the total at 114 DAP (Figure 3i).

The highest demand of Fe was verified between 42 and $78 \mathrm{DAP}$, when $17.8 \mathrm{mg} \mathrm{plant}^{-1}$ were accumulated which represented $88 \%$ of the total accumulated by the leaves. Fe accumulation in the stem showed a slight decrement from $30\left(2.7 \mathrm{mg} \mathrm{plant}^{-1}\right)$ to $90 \mathrm{DAP}$, when it was of $2.3 \mathrm{mg} \mathrm{plant}^{-1}$ (Figure $3 \mathrm{j}$ ).

The largest amount of Fe at 90 DAP was observed in tubers $\left(22.1 \mathrm{mg} \mathrm{plant}^{-1}\right)$, followed by the leaves $(20.2 \mathrm{mg}$ plant $^{-1}$ ) and stems (2.3 mg plant ${ }^{-1}$ ), as shown in Figure 3j. Yorinori (2003) and Fernandes (2010), in, respectively, plants of the 'Atlantic' and 'Asterix' cultivars, reported the tubers and the leaves to be the plant parts in which Fe accumulated most. 


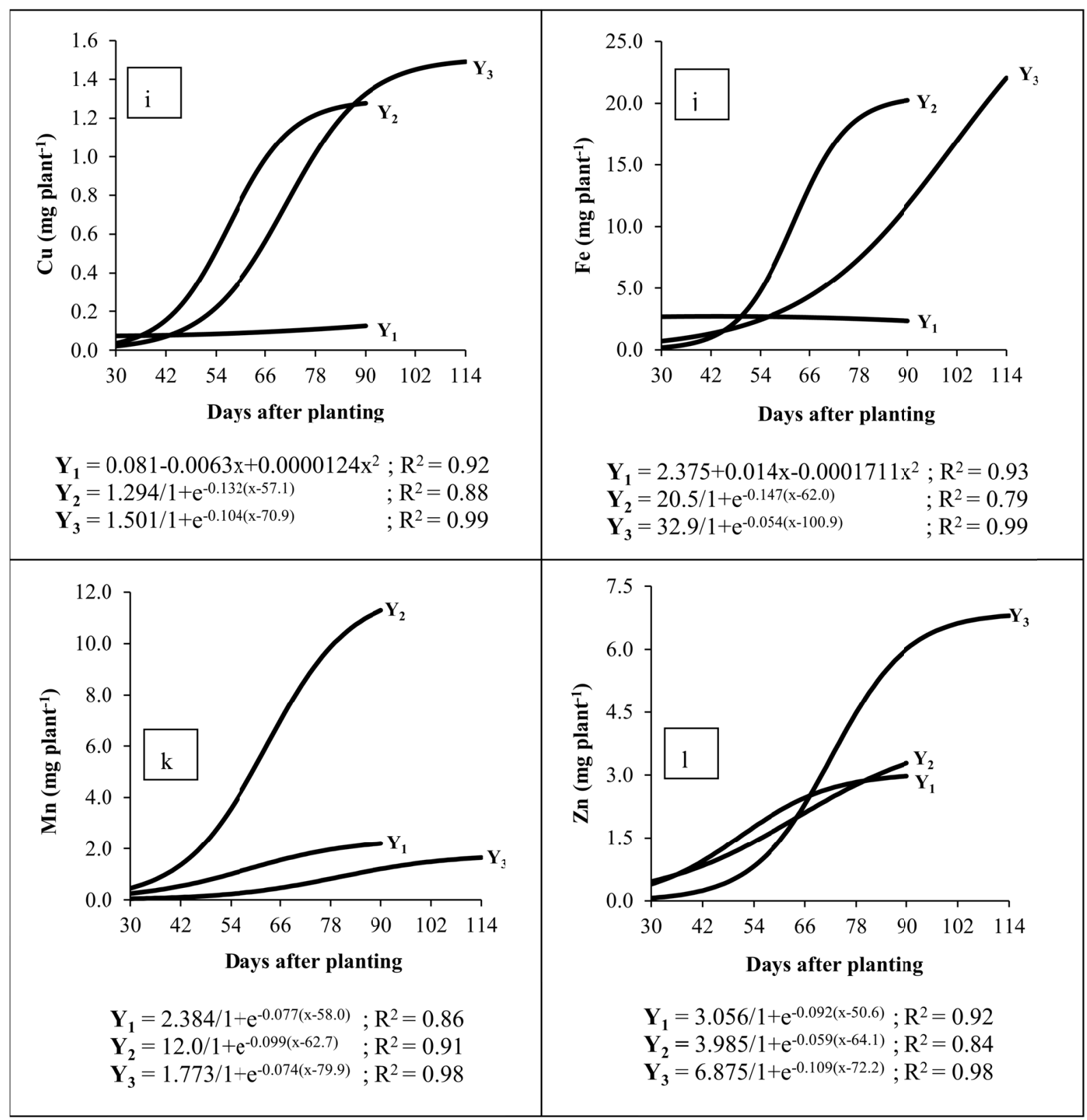

Figure 3. $\mathrm{Cu}(\mathrm{i}), \mathrm{Fe}(\mathrm{j}), \mathrm{Mn}(\mathrm{k})$ and $\mathrm{Zn}(1)$ accumulation in stems $\left(\mathrm{Y}_{1}\right)$, leaves $\left(\mathrm{Y}_{2}\right)$, and tubers $\left(\mathrm{Y}_{3}\right)$ of potato (cv. 'Asterix') plants during their growth cycle

Manganese, due to its being of low mobility in plant tissues (such as $\mathrm{Ca}$ ), was found predominantly in leaves with tubers being the plant part where the lowest amounts were found (Figure 3k). Data reported by Yorinori (2003), Heard (2004), and Fernandes (2010) also pointed the leaves of, respectively, cultivars 'Atlantic', 'Ranger Russet', and 'Asterix', as the plant part in which Mn accumulated most.

Leaves accumulated Mn continually during the whole cycle showing, at 90 DAP, an amount of that nutrient of $11.3 \mathrm{mg} \mathrm{plant}^{-1}$. At that same point, the potato plant showed a total of $14.7 \mathrm{mg} \mathrm{plant}^{-1}$ (Figure $3 \mathrm{k}$ ) of which $77 \%$ were in the leaves, $15 \%$ in the stems, and $8 \%$ in the tubers.

Between 45 and 90 DAP, tubers showed the largest accumulation of Mn with a total of $1.1 \mathrm{mg} \mathrm{plant}^{-1}$, which corresponded to $69 \%$ of the total accumulated $\left(1.6 \mathrm{mg} \mathrm{plant}^{-1}\right)$ by the plant at the end of its cycle, as shown in Figure 3k. 
The accumulation of $\mathrm{Zn}$ in leaves and stems had similar adjustments but the accumulation in the stems was always superior to that observed in the leaves. Similar behavior was observed for $\mathrm{Ca}$.

Stems and leaves accumulated $\mathrm{Zn}$ continuously and the maximum amounts of $\mathrm{Zn}$ in leaves and stems were, respectively, of 3.3 and $3.0 \mathrm{mg}$ plant $^{-1}$ at 90 DAP (Figure 31), before complete foliar senescence. Of the total $\mathrm{Zn}$ in the plant, $27 \%$ were in the leaves, $24 \%$ in the stems, and $49 \%$ in the tubers.

Up to 63 and 67 DAP, most of the Zn accumulated, respectively, in leaves and stems. After that, most of the $\mathrm{Zn}$ was accumulated in the tubers where, $114 \mathrm{DAP}$, it reached $6.8 \mathrm{mg} \mathrm{plant}^{-1}$ (Figure 31). Yorinori (2003) and Heard (2004) reported that $\mathrm{Zn}$ accumulates more in tubers. Working with plants of the 'Asterix' cultivar, Fernandes (2010) verified an amount of $10.5 \mathrm{mg} \mathrm{plant}^{-1}$ of $\mathrm{Zn}$, a value close to the one we found in this work, that is, 13.1 mg plant ${ }^{-1}$.

The nutritional demand of potato plants of the 'Asterix' cultivar may be more properly assessed by the amounts of nutrients present in the plant 90 DAP, a moment when stems and leaves were still present and had not undergone appreciable drying. At that moment, considering the plant population used in this experiment which was of 35714 plants ha ${ }^{-1}$ with a productivity of $44 \mathrm{t} \mathrm{ha}^{-1}$, the macronutrients $\mathrm{N}, \mathrm{P}, \mathrm{K}, \mathrm{Ca}, \mathrm{Mg}$, and S had, respectively, accumulated to the levels of $184.0,18.0,368.3,42.7,16.2$, and $13.8 \mathrm{~kg} \mathrm{ha}^{-1}$ and the micronutrients $\mathrm{B}, \mathrm{Cu}, \mathrm{Fe}, \mathrm{Mn}$, and $\mathrm{Zn}$ to the levels of $164,96,1,225,525$, and $439 \mathrm{~g} \mathrm{ha}^{-1}$, respectively. Thus the accumulation of nutrients by potato plants of the 'Asterix' cultivar took place according to the following decreasing order: $\mathrm{K}$, $\mathrm{N}, \mathrm{Ca}, \mathrm{P}, \mathrm{Mg}, \mathrm{S}, \mathrm{Fe}, \mathrm{Mn}, \mathrm{Zn}, \mathrm{B}$, and $\mathrm{Cu}$.

The amounts of exported nutrients, those found in tubers, were of $73,85,62,6,65,76,59,48,34,8$, and $49 \%$ of the total accumulated of $\mathrm{N}, \mathrm{P}, \mathrm{K}, \mathrm{Ca}, \mathrm{Mg}, \mathrm{S}, \mathrm{B}, \mathrm{Cu}, \mathrm{Fe}, \mathrm{Mn}$, and $\mathrm{Zn}$.

\section{Conclusions}

The results of this research work showed that growth of potato plants of the 'Asterix' cultivar was slow up to 42 DAP and that, from 51 up to 90 DAP, growth was faster with a mean estimated daily growth rate of $6.5 \mathrm{~g} \mathrm{plant}^{-1}$ day $^{-1}$. At 90 DAP, the amount of dry matter accumulated in the tubers was larger than that of the aerial biomass. At that moment, the potato plants had accumulated 369.3, 184.0, 42.7, 18.0, 16.2, and $13.8 \mathrm{~kg} \cdot \mathrm{ha}^{-1}$ of K, N, Ca, P, $\mathrm{Mg}$, and $\mathrm{S}$, respectively, and 1,225, 525, 439, 164, and $96 \mathrm{~g} \mathrm{ha}^{-1}$ of Fe, Mn, Zn, B, and $\mathrm{Cu}$, respectively.

\section{References}

Aguilar, J. L., Martínez, J. J., Volke, V., Etchevers, J., Sánchez, P., \& Aveldaño, R. (2001). Acumulación y distribución de la materia seca en papa cultivada con fertigación por goteo superficial e subsuperficial. Rev. Fitotec. Mex., 24(1), 9-16.

Alva, A. K., Hodges, T., Boydston, R. A., \& Collins, H. P. (2002). Dry matter and nitrogen accumulations and partitioning in two potato cultivars. J. Plant Nutr., 25(8), 1621-1630. http://dx.doi.org/10.1081/PLN-120006047

Alvarez-Sánchez, E., Etchevers, J. D., Ortiz, J., Núñez, R., Volke, V., Tijerina, L., \& Martínez, A. (1999). Biomass production and phosphorus accumulation of potato as affected by phosphorus nutrition. J. Plant Nutr., 22(1), 205-217. http://dx.doi.org/10.1080/01904169909365618

Bataglia, O. C., Furlani, A. M. C, Teixeira, J. P. F., Furlani, P. R., \& Gallo, J. R. (1983). Métodos de análise química de plantas. Campinas, São Paulo: Instituto Agronômico (Boletim Técnico, 78).

Bertsch, F. (2003). Absorción de nutrimentos por los cultivos. San José, Costa Rica: ACCS.

Cabalceta, G., Saldias, M., \& Alvarado, A. (2005). Absorción de nutrimentos en el cultivo de papa MNF-80. Agron. Costarricense, 29(3), 107-123.

Coraspe-León, H. M., Muraoka, T., Franzini, V. I., Piedade, S. M. de S., \& Granja, N. do P. (2009). Absorción de macronutrientes por plantas de papa (Solanum tuberosum L.) en la producción de tubérculo-semilla. Interciencia, 34(1), 57-63.

EMBRAPA. (2006). Sistema brasileiro de classificação de solos (Segunda edição). Rio de Janeiro: Centro Nacional de Pesquisa de Solos.

FAO. (2011). Production, crops. Retrieved from http://faostat.fao.org/site/567/default.aspx\#ancor

Favoretto, P. (2005). Parâmetros de crescimento e marcha de absorção de nutrientes na produção de minitubérculos de batata cv. Atlantic. Dissertação de Mestrado. Escola Superior de Agricultura "Luiz de Queiroz", Universidade de São Paulo, Piracicaba, São Paulo, Brasil. 
Fernandes, A. M. (2010). Crescimento, produtividade, acúmulo e exportação de nutrientes em cultivares de batata (Solanum tuberosum L.). Dissertação de Mestrado. Faculdade de Ciências Agronômicas de Botucatu, Universidade Estadual Paulista, Botucatu, São Paulo, Brasil.

Filgueira, F. A. R. (2003). Novo manual de olericultura: agrotecnologia moderna na produção e comercialização de hortaliças. (Segunda edição). Viçosa, Minas Gerais: Universidade Federal de Viçosa.

Fontes, P. C. R. (1999). Batata. In A. C. Ribeiro, P. T. G. Guimarães, \& V. H. Alvarez V. (Eds.), Recomendação para o uso de corretivos e fertilizantes em Minas Gerais: $5^{\circ}$ Aproximação (p. 179). Viçosa, Minas Gerais: Comissão de Fertilidade do Solo do Estado de Minas Gerais.

Geremew, E. B., Steyn, J. M., \& Annandale, J. G. (2007). Evaluation of growth performance and dry matter partitioning of four processing potato (Solanum tuberosum) cultivars. New Zeal. J. Crop Hort., 35, 385-393. http://dx.doi.org/10.1080/01140670709510204

Heard, J. (2004). Nutrient accumulation and partitioning by potatoes in Manitoba. In: Proceedings of the Manitoba Soil Science Society. Winnipeg, Manitoba, Canada.

Horneck, D., \& Rosen, C. (2008). Measuring nutrient accumulation rates of potatoes - tools for better management. Better Crops, 92, 4-6.

IBGE (2011). Produção agrícola municipal 2009. Retrieved from http://www.ibge.gov.br/estadosat/

Malavolta, E. (2006). Manual de nutrição mineral de plantas. São Paulo: Ceres.

Mora-Aguilar, R., Ortiz-Cereceres, J., Rivera-Peña, A., Mendoza-Castillo, M. C., Colinas-León, Ma. T., Lozoya-Saldaña, H., \& Rodríguez-Pérez, J. E. (2005). Comportamiento de la acumulación y distribución de biomasa en genotipos de papa establecidos en condiciones de secano. Rev. Chapingo Ser. Hortic., 11(1), $135-142$.

Ñústez, C. E., Santos, M., \& Segura, M. (2009). Acumulación y distribución de materia seca de cuatro variedades de papa (Solanum tuberosum L.) en Zipaquiará, Cundinamarca (Colombia). Rev. Fac. Nal. Agr. Medellín, 62(1), 4823-4834.

Sancho, H. (1999). Curvas de absorción de nutrientes: importancia y uso en los programas de fertilización. Informaciones Agronómicas, 36, 11-13.

Sharifi, M., Zebarth, B. J., Hajabbasi, M. A., \& Kalbasi, M. (2005). Dry matter and nitrogen accumulation and root morphological characteristics of two clonal selections of 'Russet Norkotah' potato as affected by nitrogen fertilization. J. Plant Nutr., 28, 2243-2253. http://dx.doi.org/10.1080/01904160500323552

Yorinori, G. T. (2003). Curva de crescimento e acúmulo de nutrientes pela cultura da batata cv. Atlantic. 2003. Dissertação de Mestrado. Escola Superior de Agricultura "Luiz de Queiroz", Universidade de São Paulo, Piracicaba, São Paulo, Brasil.

\section{Copyrights}

Copyright for this article is retained by the author(s), with first publication rights granted to the journal.

This is an open-access article distributed under the terms and conditions of the Creative Commons Attribution license (http://creativecommons.org/licenses/by/3.0/). 